\title{
Judicial Protection of Private Property Rights in Ethiopia: Selected Themes
}

\author{
Hailu Burayu, Elias N. Stebek \& Muradu Abdo *
}

\section{Introduction}

The protection of property rights involves complementarities between the judiciary, executive organs and administrative tribunals. It envisages a legislative framework and administrative protection based on an administrative procedure law pursued by administrative authorities and tribunals. Moreover, It requires an independent and competent judiciary with due integrity.

The judicial protection of private property rights determines the extent to which individuals and legal persons are ensured access, proper interpretation, efficient adjudication and appropriate judgment to their claims, counterclaims and defenses whenever disputes are adjudicated in courts of law. This envisages competence, integrity, efficiency, judicial independence, predictability and consistency in judicial decisions. As an exhaustive analysis on all aspects of these themes requires wider discussion, this comment focuses on the jurisprudence, consistency and predictability of some high level Ethiopian court decisions (particularly at the level of the Cassation Division of the Federal Supreme Court) on selected themes related to private property with a view to highlighting the practical protection of private property rights in Ethiopia.

- Hailu Burayu (LL.B, LL.M; Consultant and Attorney at Law); E. N. Stebek (LL.B, LL.M, PhD; Associate Professor); Muradu Abdo (LL.B, LL.M, PhD Candidate; Asst. Professor).

This comment is an abridged version of the fourth chapter of the research titled "Property Rights Protection and Private Sector Development in Ethiopia" which was submitted to Private Sector Development Hub at the Ethiopian Chamber of Commerce and Sectoral Associations. The authors are grateful to Private Sector Development Hub for sponsoring the research in partnership with SIDA (Swedish International Development Cooperation Agency). 


\section{Overview of some cases that involve land rights}

The current land holding system in Ethiopia gives power to both the federal and regional states to enact laws pertaining to land. The Federal Supreme Court's Cassation Division decisions also bind lower courts in the interpretation of similar issues as per Article 2(4) of Proclamation No. 454/2005. Therefore, reference to the Cassation Division decisions on land rights is necessary to examine the protection of property rights.

Land rights are crucial in private sector development as no investment can be carried out without land. ${ }^{1}$ Article 1130 of the Civil Code gives recognition to land and buildings as immovables, and Article 1204 states the elements of ownership regarding the use, enjoyment of its fruits, and its disposal through donation, sale or inheritance, etc. as envisaged under Article 1205. Article 1206 of the Civil Code entitles the owner "to claim his property from any person who unlawfully possesses or holds it and may oppose any act of usurpation".

Disputing parties may settle their difference with or without the involvement of a third party, or through mediation or arbitration. Yet, going to courts of law becomes necessary when resolving a dispute becomes impossible by the parties themselves or through mediation or arbitration. The following cases show few of the themes that can give an overview of the problems of predictability, consistency and delay in the adjudication of property rights.

\subsection{The need to recognize the economic value of land use rights}

a) G/Egizabher v. Selamawit, FSC Cassation Division (File number 26130) ${ }^{2}$

The case started in the Tigray National Regional State. The mother of Selamawit, Dinkinesh Demisu (deceased), was married to G/Egizabher. After the death of her mother W/t Selamawit claimed a house with 10 rooms as heir to her mother. The deceased had 5 rooms built on the land before she married G/Egziabher, and they built 5 more rooms on the land after their marriage.

The High Court of Tigray decided that the rooms built after marriage should be shared between G/Egziabher and Selamawit but part of the house built before marriage (i.e five rooms) would exclusively belong to Selamawit and the court

\footnotetext{
${ }^{1}$ As stated in Chapter 1, land is no more within the realm of private property under the existing laws of Ethiopia: i.e., Proclamation No. 31/1975 that has made rural land public property, and proclamation No. 47/1975 that renders urban land the property of the state and the Ethiopian people. Private citizens thus only exercise possessory rights not ownership right on rural or urban lands.

2 Alem Asmelash, (2010) "Comments on Some Land Rights Related Decisions of the Federal Supreme Court Cassation Division", Ethiopian Journal of Legal Education, Vol. 3, No. 2, pp. 154-156 (abridged)
} 
added that if it is possible, the land should be equally divided between the two. In case this is not possible, the court decided that the house should be sold and they should share the amount based on the proportion stated by the court. But there was a dissenting opinion which stated that since the land was what the deceased got before her marriage to G/Egziabher, the latter could only share from the values of five rooms built after marriage and not the land.

The dissenting opinion was upheld upon an appeal to Tigray Supreme Court, and the Tigray Supreme Court Cassation Division affirmed the decision of the Tigray Supreme Court. Petition was lodged to the Cassation Division of the Federal Supreme Court. The Division in rendering its judgment stated that individuals do not have ownership right over land but only that of possession. The court further stated that the mother of Selamawit had together with her husband built the extra five rooms after her marriage thereby conceding her possessory right on the land, and G/Egziabher's share on the house cannot be seen separately from the land built on it.

From the decision of the Division, it can be inferred that the land and the house are intrinsic elements and that one cannot see the house separately from the land built on it so far as the current land laws are concerned. This interpretation evokes two questions: Can the immovable property be an intrinsic element of another immovable property? And are the rules of accession relevant to interpretation of the Federal Supreme Court Cassation Division?

Regarding the first question, Article 1132 of the Civil Code of Ethiopia defines 'intrinsic elements'. Article 1130 merely states land and buildings as immovables, and the provisions that define intrinsic elements and accessories are Articles 1130 to 1134 . Trees and crops are clearly stated as intrinsic elements of the land until they are separated or until they are "subject of contract" which envisages their separation. The right in rem over the trees is determined by the right in rem over the land, and as a result any other party who has claim over the trees or crops has right in personam over the person who has ownership/possessory title over the land and not a right in rem over the trees or crops as long as they are intrinsic elements of the land. ${ }^{3}$ As Stebek notes:

the Civil Code is cautious with regard to buildings, and merely defines them as immovables under Art. 1130. It rather treats the scenario of separate claims over land and buildings under the provisions that deal with accession. Articles 1178 and 1179 of the Civil Code envisage two different scenarios whereby a person has constructed a building without the objection of the landowner (Art. 1179), or where the building is constructed against the will of the landowner (Art. 1178). If the landowner did not object to the construction of a building, the builder could own the building but still the landowner can evict the builder upon payment of compensation. In case,

\footnotetext{
${ }^{3}$ Elias N. Stebek (2012), Case Comment, unpublished.
} 
however, the house is built against the will of the landowner, the landowner may at his option evict the builder without the payment of compensation. Even if land has come under public ownership in Ethiopia since 1975, these provisions can apply mutatis mutandis to ownership over land use rights, i.e. possessory rights over land.

Since the deceased and G/Egziabher were in wedlock, the five rooms were built without the objection of the deceased. Thus, the law on accession enables the landowner (in this case the landholder) to evict the builder but should pay compensation. This clearly means, right in rem over all the rooms (including the ones built during the marriage) belongs to the deceased while $\mathrm{G} /$ Egziabher is entitled to right in personam, i.e compensation for his share in the co-ownership of the five rooms built after the marriage. ${ }^{4}$

In estates owned by companies or in case of joint ownership, land use rights may be capital contributions and in effect, the ownership of the use right over the land goes to the company or the joint owners thereby rendering Articles 1178 and 1179 inapplicable. In the case of G/Egizabher v. Selamawit, however, there were already five rooms over the land to which the deceased has landholding title, and issue of joint ownership of use rights over the land cannot arise. ${ }^{5}$ Therefore, the Federal Supreme Court (FSC) Cassation Division's decision does not seem to have legal basis. If equity is its basis, there can also be an argument in favour of Selamawit that it is inequitable and unjust to disregard the use right over the land that her mother had before the marriage.

Fillipos Aynalem, ${ }^{6}$ in assessing the same issue, observes that the provisions of the Civil Code Articles 1178 and 1179 enable us to separate the right of land possession/ownership from ownership over the building built on it. He further notes that public ownership of land does not deny citizens to have possessory right that is worthy in the eyes of the law, and underlines that the Constitution protects the possessory right of the land.

In G/Egizabher v. Selamawit, the accession rules embodied in the Civil Code have been unduly disregarded. The Division held that a person with a claim over a house shall also have a right over the use right on land no matter who the initial possessor of the land was, and the land cannot be seen differently from the house. Decisions of the FSC Cassation Division bind lower courts with regard to interpretation. This binding interpretation thus applies to similar issues in all courts of law unless the FSC Cassation Division amends it in its future

\footnotetext{
${ }^{4}$ Ibid.

${ }^{5}$ Ibid.

${ }^{6}$ Filipos Aynalem (2009), "[Interpretation of Possessory Rights over Urban Land (Amharic)] Phr. 1, August 2009.
} 
decisions. It is to be noted that even interpretations in which the court had erred remain applicable on all lower court decisions that have pursued the interpretation because the FSC Cassation Division's decisions to reverse its former erroneous interpretation can only have prospective and not retroactive effect based on its recent decision under File No. $68773 .^{7}$

The impact of this interpretation in private sector development is that it discourages the expansion of family owned business premises and rental property. In case of large-scale investments, land use rights can easily be capital contributions and spouses, joint owners, family members and shareholders can from the outset define their shared land use rights. In small scale improvements (such as modest renovations for business activities, rentals, etc.), however, a spouse who has real right over residential or business premises can (upon second marriage, for instance) be reluctant against expansion or improvement of the property during marriage owing to the risk of its conversion to common property. This significantly affects private sector development, as the supply side of business premises envisages not only big constructions of companyowned malls, but also small and medium shop premises that can benefit from small-scale renovations, expansions and improvements.

\section{b) Ethiopian Road Authority v. Issa Mohammed (File number 30461) ${ }^{8}$}

The case started in Illubabor, Oromia National Regional State. Issa had license to produce sand on the land he was given through lease. But while a road was being built on the area, the Ethiopian Roads Authority took the already produced sand worth Birr 30,000 that belonged to Ato Isssa. He instituted a case at the Oromia High Court, and the court ordered the Ethiopian Roads Authority to pay the amount. On appeal, the Oromia Supreme Court affirmed the decision of the High court. Thus, the case went to the FSC Cassation Division.

The Federal Supreme Court Cassation Division held that by virtue Article 6(18) of the Ethiopian Roads Authority Re-establishing Proclamation 80/1997, the Authority can, for the purpose of road construction and maintenance and other purposes, use land and stone-like resources for free and is only obliged to pay compensation for properties of the land. It reversed the decision of the Oromia Supreme Court which had held that the Ethiopian Roads Authority Reestablishing Proclamation 80/1997 does not allow the Authority to take away sand found on the land held by another person. On the contrary, the FSC Cassation Division remarked that since land and all natural resources are owned

\footnotetext{
${ }^{7}$ Getachew Deyas and Fantu Tesfaye v. Rukia Kedir, File No. 68773, Federal Supreme Court Cassation Division Decisions, Vol. 13, pp. 623-625.

${ }^{8}$ Cassation File No. 30461, Hidar 3, 2000 E.C., published in Mizan Law Review, Vol. 3 No. 2 (2009).
} 
by the people and the government, the latter and the people should use the resources for free.

The FSC Cassation Division held that even if Issa had the license to produce sand, the resources are owned by the government and the people, and the latter can legitimately take away the resources. Issa's plea for the value of the sand and for the expense incurred to produce the sand was rejected and the Cassation Division decided that the Ethiopian Road Authority is not obliged to pay the amount.

This decision does not recognize the economic value of use rights on land, and it takes the interpretation of Article 40(3) of the Constitution to its extreme application. This allows a government entity to take any resource obtained from land without compensation even if a person extracts the resource based on a license to undertake a business activity.

The court should have made a distinction between the Authority's entitlement to extract sand and the act of confiscating another person's property which is already extracted and ready for transportation. Distinction should have also been made between ownership vis-à-vis the limited scope of bare ownership (plus regulatory powers) that the state has over land on which a person has use right. While the state is the bare owner who is entitled to collect lease price, land rent, etc., the right to use and enjoy the products from the resource clearly belongs to the landholder.

The case Ethiopian Roads Authority v. Genenew W/Yohannes also involved sand taken by the Authority in which the Cassation Division affirmed the decision it rendered in the case Ethiopian Roads Authority v. Issa by stipulating that there is no legal ground for the Authority to be obliged to pay for the value of sand it took from Genenew. ${ }^{9}$ The Cassation Division stated that all resources belong to the people and the government, and thus the government should not be obliged to pay compensation for the resources.

Apparently, the sand is not in its natural state in both cases. A person holding license to extract sand in a given location (stated in the license) spends time and energy to extract sand thereby adding value to it. Although Ethiopian Roads Authority is going to use the sand for road construction, it would have been fair to order the Authority to pay compensation for the sand. This is a clear example of the Cassation Division's jurisprudence which disregards economic value to the use rights on land. This should indeed be rectified because private business development envisages recognition to the use value of land to which an individual or a legal person is entitled.

\footnotetext{
${ }^{9}$ Cassation File No. 57593.
} 


\subsection{Judicial authority to examine administrative revocation of landholding title}

In File No. $22719^{10}$ a petition to the FSC Cassation Division was lodged by Addis Ababa Urban Land Administration and Urban Development Bureau in which the petitioner sought reversal of the decision of lower courts which required the Bureau to withdraw its unlawful revocation of landholding and house ownership titles. The Bureau had revoked land holding title No.32221 and house ownership title No. 17/3/91, an act that was contested by Negash as unlawful. The lower court examined the case and rendered its decision in favour of Negash Dubale in File No. 503/88 that required the Administrative Bureau to issue landholding and house ownership titles for House Numbers 1304, 1305 and 1306 situated in Higher 17 Kebele 20. Execution proceeding of the decision was further instituted under File No. 90/92 based on which the Bureau was ordered to allow the continued validity of the landholding title and the house ownership title.

The FSC Cassation Division ruled that as long as the Bureau has revoked the landholding and house ownership titles of the houses, there is no vested interest (as per Article 33(2) of the Civil Procedure Code) that justifies judicial litigation, and the lower courts should not have adjudicated the case. The Cassation Division held that the law confers authority over the administrative authority to provide or revoke such titles, and any grievance in this regard should have been instituted not in courts of law but in the complaint procedures of the relevant administrative authority. This decision and its aftermath clearly affect the protection of private property rights and private sector development.

The landholding and house ownership titles were issued to Negash which render him holder of property rights. As long as the revocation was contested in a court of law, the administrative authority is clearly duty bound to justify the

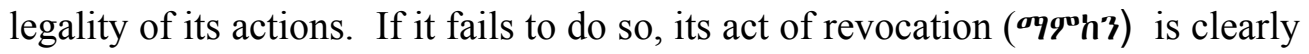
an ultra vires act which, according to Article 401 of the Civil Code, is of no effect. In other words, as long as the Bureau had no authority to revoke the landholding and house ownership titles, it is void $a b$ initio (void from the beginning), and the revocation should have been declared of no effect.

Article 401(1) of the Civil Code provides that "Acts performed by the bodies referred to in [Article $394 \mathrm{ff}$ ] in excess of the powers given to them by law or without the observance of the conditions or formalities required by law shall be of no effect". This applies even if it is not "expressly provided by law in such

\footnotetext{
${ }^{10}$ Addis Ababa Urban Land Administration and Urban Development Bureau v. Negash Dubale, Federal Supreme Court Cassation Division Decisions, Vol. 6, pp. 176-178.
} 
circumstances". ${ }^{11}$ According to Art. 402, the nullity may be invoked by any interested party.

Administrative authorities should not thus be entitled to confer and revoke property rights at will, and it is the role of courts to examine and annul ultra vires acts. Or else, the ultimate fate of property rights holders would depend on the good intentions or adverse decisions of administrative authorities which may be arbitrary. Fortunately, there are recent developments in favour of a new line of interpretation in the Federal Supreme Court regarding the authority of courts to examine the legality of the issuance or revocation of landholding title deeds where it becomes an issue in the course of litigation. The decisions of the Federal Supreme Court Cassation Division in File No. 67011 (Taitu Kebede's Heirs v. Tirunesh et al), File No. 64014 (Genet Seyoum v. Kirkos Sub-City Kebele 17/18 Administration et al) and File No. 48217 (Abadit L. v. Zalambesa Town Administration \& Berhane Z.) illustrate this fact.

\subsection{Contractual benefits in the absence of landholding titles}

Teklemariam ${ }^{12}$ built a house (House No. 367(b)), Woreda 17, Kebele 15 and he rented it to Adane who in return, without seeking consent from the lessor rented some part of the house to Fetlework. The tenant refused to pay him the rent, and Teklemariam brought an action against him. Adane requested the court to allow the Addis Ababa land Administration to intervene in the litigation on the ground that the lessor (Teklemariam) does not have landholding title for the land or house construction permit to build the house. Both lower courts rejected the objections and ordered the respondents to pay the arrears of the rent and handover the house to Teklemariam.

The lessees filed a petition at the Federal Supreme Court Cassation Division. The Cassation Division decided in favor of the intervener (Addis Ababa City Land Administration) on the ground that the lessor has no landholding title and house construction permit. The respondents (lessees) were required to handover the land and the house to the intervener (Addis Ababa City Land Administration) on the ground that urban land belongs to the state, and it cannot be owned privately.

The two grounds that constituted the basis for the decisions of the lower courts were first, no evidence has been produced which proves that the particular land under consideration is nationalized, and secondly the illegal construction of the house is an issue that can only be invoked by the relevant administrative entities and not by the lessees.

${ }^{11}$ Civil Code, Art. 401(2).

${ }^{12}$ Addis Ababa City Administration v. Teklemariam Mekonnen (File Number 24269)

Federal Supreme Court Cassation Division Decisions, Vol. 6, pp. 185-187. 
The issue in litigation should have been whether there is a contract between the parties in dispute, and the issue of title should have been a different issue that could have been handled by the relevant administrative offices. According to Article 1732 of the Civil Code, "contracts shall be interpreted in accordance with good faith having regard to the loyalty of confidence which should exist between the parties according to business practice." The lessee who invokes the issue of landholding title clearly intends to avoid payment of the house rent, because the existence or nonexistence of landholding title or house construction permit is not among the relevant elements for the services obtained in the course of using the premises.

Even if there was a law that could have rendered such contracts untenable and invalid (owing to defects in the property rights of the lessor), the contracting parties should have, by virtue of Article 1815 of the Civil Code, been reinstated to their pre-contract positions because the provision clearly provides that upon invalidation of a contract "the parties shall be as much as possible be reinstated in the position which could have existed, had the contract not been made."

According to Article 1179(1) of the Civil Code, "Whosoever has erected a building on land [which is] the property of another [person] without the landlord objecting to the building shall be the owner of such building." However, the relevant authority can order the demolition of any construction that is made without prior permit, according to Article 7(1) of Construction and Use of Urban Houses Proclamation No. 292/1986.

Such houses are not built overnight and there is a house number given to the house. This implies that the administrative entity that has given number to the house is aware of its construction. Many illegal holdings and constructions have been regularized where they do not violate the basic master plan and redevelopment plans of the city. Accordingly, the lessor could have been beneficiary in the regularization schemes undertaken by Addis Ababa City Administration in series of rounds.

In Gezahegn Adinew v. Dasash Baynesagn, ${ }^{13}$ the Federal Supreme Court Cassation Division pursued a different line of interpretation over a relatively similar issue. The petitioner built a house on the land of the respondents based on permission obtained from them. Due to disagreement, the respondents evicted the petitioner from their land. The lower courts entitled Gezahegn to receive one fourth of the price of the house as per Art 1180(2) of the Civil Code, and required him to surrender the house to respondents. However, the FSC Cassation Division reversed the decision of the lower courts on the ground that land belongs to the state and peoples of Ethiopia, and hence respondents do not have the right to allow a house to be constructed on any piece of land that does

${ }^{13}$ Gezahegn Adinew v. Dasash Baynesagn, File No. 30101, Federal Supreme Court Cassation Division Decisions, Vol. 6, pp. 203-205. 
not belong to them. On the basis of this decision, the petitioner became an owner of a house that he built on a piece of land given to him by individuals who have no legal power to do so. The relevance of such cases is that there ought to be predictability and consistency in case analysis and decisions.

\subsection{Examples of Delay in court decisions and challenges in the enforcement of court decrees}

Delay in court decisions and execution of judgments is among the challenges that adversely affect property rights protection. For example, there has been a delay of six years to decide on the amount suggested by independent chartered accountants in relation to financial report submitted by the plaintiff in Habteab Tesfa Building Construction Contractor v. Ethiopian Telecommunication Corporation (File No. 31934). The case is still pending at the Federal First Instance Court. While the claim involves Birr 400,000, the auditor's suggested figure is Birr 388,000

The challenges in the reluctance of various administrative organs to enforce court decisions and decrees can be illustrated by the following examples that are stated in the decision rendered by the Cassation Division of the Federal Supreme Court in Tewolde Bisrat et al, Tahsas 04, 2004 E.C, File No. $67777^{14}$ :

a) In Prosecutor v. Tekabe, Criminal Cases File No. 162887, the court ordered release on bail on Tir $2^{\text {nd }} 2002$ E.C. (January 10, 2010), but Tekabe stayed under detention in the Customs and Revenue Administration Police Station for ten months.

b) Mesfin Kassahun (File No. 169690) was released 6 months after court order for release on bail was issued on Ginbot 24, 2002 E.C (June 1, 2010).

c) Hailu Worku and Louisa Farmeta (File No. 167550) were imprisoned for over eight months after the court's order that they be released on bail.

d) Mengistu Abraham and Ahmed Mohammed (File No. 172759) and Bamlak Yismaw (File No. 170203) stayed for over 3 months at Customs Police after court decisions of release on bail.

\section{Subjecting Expropriation Disputes to Judicial Scrutiny}

Some might argue that the imbalance created by the present expropriation laws of Ethiopia can be rectified if the judiciary was allowed to entertain major disputes relating to expropriation including the question of public purpose. Nevertheless, allowing persons affected by land expropriation to resort to regular courts might not necessarily work in favor of the poor if there is deficit

${ }^{14}$ Tewolde Bisrat et al, Tahsas 04, 2004 E.C., File No. 67777, Federal Supreme Court Cassation Division Cassation Decisions, Vol. 13, pp. 266-270. 
in the independence of the judiciary in relation to cases that are deemed or perceived to matter to the authorities.

In Ethiopia, there had been a historic formal fusion between the judiciary and the executive impacting the present independence of the former. Assefa notes: ${ }^{15}$

In historic Ethiopia, adjudication of cases formed part and parcel of public administration. One finds a merger of functions within the executive, the administration of justice and the executive function proper. ...This blend of judicial and executive functions in the latter is not without implications. First and foremost, the judiciary never had a separate existence of its own as an institution. It was subject to all kinds of pressures from the other branches.

Currently, the country`s judicial system has moved away from its earlier formal dependence towards its legal and constitutional independence. But there are doubts about its detachment in reality from the legacy of dependence. At present, the judiciary`s formal independence is unambiguously stated in the FDRE Constitution, which declares that: "An independent judiciary is established... Courts of any level shall be free from any interference of...any governmental body, government official or from any other source...judges shall be directed solely by the law. "16

Yet, "[t]here is a perception that the autonomy of the judiciary in Ethiopia is weak..." Assefa states "...external pressure on the judiciary has deep roots and

${ }^{15}$ Assefa Fiseha, Federalism and the Accommodation of Diversity in Ethiopia: A Comparative Study (hereinafter Federalism and Accommodation), (Netherlands, Wolf Legal Publishers, 2005/06) p. 390; see also Chi Mgbako et al, Silencing the Ethiopian Courts: Non-Judicial Constitutional Review and its Impact on Human Rights, 32 Fordham International Law Journal1 259 (2008); where it is asserted that "The executive branch has the power to do as it wishes with no judicial checks on its activities..." at 289-290 \& 296. See also Tigist Assefa, Judicial Review of Administrative Actions: A Comparative Analysis (LL.M Thesis, School of Law, Addis Ababa University,) (2010) available at $<$ http://etd.aau.edu.et/dspace/bitstream/123456789/2154/1/Tigist\%20Asefa.pdf $>$ (Accessed: December, 22, 2011).

${ }^{16}$ See Article 78/1 and Article 79/2\& 3 of the FDRE Constitution.

${ }^{17}$ African Development Bank: Country Governance Profile: Ethiopia (hereinafter Country Governance Profile) (2009) at $<$ http://www.afdb.org/fileadmin/uploads/afdb/Documents/Project-andOperations/Ethiopia\%20\%E2\%80\%93\%20Country\%20Governance $\% 20$ Profile\%20E N.pdf $>$ (Accessed January 11, 2012) at 11; see also The Canadian International Development Agency, Independence, Transparency and Accountability in the Judiciary of Ethiopia (2008) (Unpublished, on file with the author) pp. 99-101 \& 135138. 
is not without some hangovers on the new federal judiciary. Administrators at state level, even today, think that it is natural to order the judge...". 18

A long history of centralized governmental authority and a judiciary subjugated to the executive branch has fostered a weak judicial branch with reduced capacity to exercise genuine independence, as well as a reticence of other branches to treat the judiciary as either truly independent or co-equal. ${ }^{19}$

In particular, “...where government interests are at stake, direct interference has been noted..."

According to the Global Competitiveness Report 2010-2011, in terms of juridical independence, Ethiopia ranks $89^{\text {th }}$ out of 139 nations, which has shown an improvement from its previous ranking, but Ethiopia`s standing is still low in the ranking index. ${ }^{21}$ This is despite the fact that the country has put in place a judicial reform program whose key objective is "the promotion of professional and autonomous judiciary". ${ }^{22}$ This is on the top of the numerous factors which inhibit the judiciary`s assertiveness, ${ }^{23}$ accessibility, effectiveness and efficiency. ${ }^{24}$ Thus, in the current state of the judiciary, it is doubtful if the judiciary would assert its autonomy in respect of cases involving land expropriations if the question of public purpose and other expropriation questions were made subject to judicial challenge.

${ }_{18}^{18}$ Assefa Fiseha, Federalism and Accommodation supra note 18, p. 390.

19 The World Bank, Judicial and Legal Assessment Judicial and Legal Assessment (2004) at $<$ http://siteresources.worldbank.org/INTLAWJUSTINST/Resources/EthiopiaSA.pdf $>$ (accessed January 11, 2012) pp. 19 \& 21-23.

${ }^{20}$ Id., at 21.

${ }^{21}$ World Economic Forum, The Global Competitiveness Report 2010-2011 at http://www3.weforum.org/docs/WEF_GlobalCompetitivenessReport_2010-11.pdf, (last viewed December 21, 2011) at $1 \overline{5}$.

${ }^{22}$ Country Governance Profile supra note 20, p. 11.

${ }^{23}$ There is a tendency to restrict the turfs of its power even in cases which are deemed ordinary. This is particularly true when it comes to reviewing the actions of executive organs. For instance, in Ethiopian Privatization and Public Enterprises Supervising Authority vs Heirs of Mr. Nour Beza, (Fed. Sup. Ct. Cassation File No. 23608, 2000E.C.) in the Decisions of the Federal Supreme Court Cassation Division Vol. 5 (Addis Ababa: Federal Supreme Court, 2001 E.C.) pp. 304-305, where the court has reasoned that in the Ethiopian context, judicial power of the regular courts is not inherent but it emanates from the positive law and that where bodies other than regular courts are given by the law the power to render final and binding decisions then regular courts cannot size upon such matters even by way of review."

${ }^{24}$ Federal Democratic Republic of Ethiopia: Comprehensive Justice Reform Program: Base Line Study Report (Amsterdam, Center for International Legal Cooperation, 2005) pp. 77-89 \& 213-227. 
The above argument should not send the message that a judiciary that operates within a modus operandi of centuries of strong judicial tradition would necessarily award a generous compensation or adopt a restrictive notion of public purpose. The latter point can be illustrated by taking the 2005 Kelo decision handed down by the US Supreme Court. ${ }^{25}$ In this case, the court has upheld the decision of a city government to take land from one private person to give it to another for economic redevelopment purpose implying the interpretation by the judiciary of public purpose broadly to mean any project that would entail direct or indirect benefit to the public in the form of tax revenues and jobs. ${ }^{26}$

But the context of the Kelo case is different from the broader notion of public purpose in place in Ethiopia. Unlike Ethiopia, the public purpose test in the US is unmistakably open to judicial scrutiny. And the Kelo expropriation took place in the context of comprehensive government plan which passed through public hearings, and followed by approval from a democratically elected local government.

The US Supreme Court delivered the Kelo decision in the context of property rights notion different from the one prevalent in the Ethiopia. The Kelo case was litigated in the country with a strong tradition of private property protection as opposed to Ethiopia where such protection has historically been weaker. In the Kelo case, those who opposed the taking by the city government argued, amongst others, that "the symbolic value of home and ownership" is "something that cannot be entirely compensated monetarily"27 perhaps because home ownership is seen as a kind of non-fungible property as articulated in Radin`s personhood theory of property as opposed to arguments based on the

${ }^{25}$ See Annette M. Kim. "Land Takings in the Private Interest: Comparisons of Urban Land Development Controversies in the United States, China, and Vietnam."

Cityscape 11.1 (2009): 19- 32. See also Antonio Azuela and Carlos Herrera-Martin (2009), "Taking Land Around the World: International Trends in Expropriation for Urban and Infrastructure Projects" in Somik V. Lall, Mila Freire, Belinda Yuen, Robin Rajack and Jean-Jacques Helluin (eds.), Urban Land Markets Improving Land Management for Successful Urbanization (Springer Netherlands); see also Daniel B. Kelly (2005), "The Public Use Requirement in Eminent Domain Law: A Rationale Based on Secret Purchases and Private Influence" Discussion Paper No. 5 07/2005, Harvard Law School at $<$ http://www.law.harvard.edu/programs/olin_center/fellows_papers/pdf/Kelly_5.pdf $>$ . (Viewed January 11, 2012) W. Keating (Book Review), Rachelle Alterman, Takings International, A Comparative Perspective on Land use Regulations and Compensation Rights, (Chicago, IL. ABA Publishing, 2010) p. 363.

${ }^{26}$ Carol L. Zeiner (2010), "Eminent Domain Wolves in Sheep's Clothing: Private Benefit Masquerading As Classic Public Use, 28 Virginia Environmental Law Journal 1 pp. 10-11.

${ }^{27}$ Annette Kim, supra note 28, p. 24. 
deprivation of the subsistence asset of people in Ethiopia. In the Kelo case, the taking of private home from high or middle income persons took place in order to advance public interest in the context of city redevelopment with a view to attracting new businesses while takings in Ethiopia occur for economic development in the sense of taking farmland from low income rural people. Unlike Ethiopia, where the expropriation law is mainly federalized, states in the US can issue their own expropriation law. For instance, after Kelo several states have passed statutes restricting the broad reach of the Supreme Court's interpretation of the standard of public use. ${ }^{28}$

\section{Selected Issues on Subletting Business Premises and Intellectual Property}

\subsection{The right to sublet business premises}

In Emebet Mekonnen v. Woreda 20 Kebele $29,{ }^{29}$ the lessee had sublet her business (a hotel) to another person without obtaining permissions from its owner, the Kebele. Emebet had made improvements worth Birr 300,000 (three hundred thousand) based on the permission she had obtained from the Kebele. The lessee later on refused to give the premises back to Emebet on the ground that the Kebele has taken its premises back, and has leased it to them. The Kebele argued that it has terminated its lease with Emebet and has let it to the new occupants who are using it for hotel business.

Article 145(1) of the Commercial Code recognizes the right of the leasee to assign or sublet or to sell his business without obtaining permission from the lessor. This includes the transfer of the right to lease the business premises. During the litigation, the Kebele invoked the Directive issued by the Government Houses Rental Agency which prohibits subletting business premises without its permission, and it argued that Emebet's acts violate this Directive and the lease contract with her is duly terminated. The High Court rejected the Kebele's arguments and decided that the Kebele did not prove its authority to terminate the contract and did not submit evidence about the termination of the rental contract between Emebet and the Kebele. It also stated that the term of sub-lease between Emebet and the persons who have refused to pay her the rent has not ended, and held that the sub-lessees are bound to pay the arrears and damages.

${ }^{28}$ Chenglin Liu (2008), "The Chinese Takings Law from a Comparative Perspective", Journal of Law \& Policy, pp. 331-332.

${ }^{29}$ Emebet Mekonnen v. Woreda 20 Kebele 29, File No. 31264, Federal Supreme Court Cassation Division Decisions, Vol. 9, pp. 140-142. 
This decision was reversed by the Federal Supreme Court, and ultimately reinstated by the Federal Supreme Court Cassation Division. The Cassation Division stated that Article 145(1) of the Commercial Code allows businessmen to sublet their business including its premises without prior permission from the owner of the premises. Likewise, the Cassation Division has (under File No. 34586) recognized the right of the lessee to sell his business without obtaining the prior consent of the lessor, i.e. Agency for Government Houses). The Cassation Division's interpretation of Article 145(1) of the Commercial Code is indeed commendable, and such decisions have significant contribution in controlling abuse of powers by administrative agencies.

A case in point is the Directive issued by the Agency for Government Houses (issued in Hedar 2004 Eth. Calendar, i.e. November, 2011) which prohibits subletting or assigning business premises to a third party. This directive clearly violates Article 145(1) of the Commercial Code which is very fundamental in the smooth operation of business activities and private sector development. Federal courts are deciding in favor of the Agency for Government Houses citing this directive (which is currently in the process of some revision), while losing parties argue that the Agency does not have the power to issue such directive. Cassation petitions are expected to be made soon.

The decision of the Cassation Division in Emebet Mekonnen v. Woreda 20 Kebele 29 was rendered in January 2009, and it remains to be seen whether the Cassation Division will maintain its position, or uphold current or future administrative directives even if they violate Article 145(1) of the Commercial Code.

\subsection{Intellectual property: Sample cases}

In Ethio-Cermaic P.L.C v. Ethiopian Intellectual Property office \& Ovorgiga Technology Limited ${ }^{30}$ the $2^{\text {nd }}$ respondent Ovorgiga Technology requested $1^{\text {st }}$ respondent to register its trademark Ethio Cement encircled with ten stars. Ethiopian Intellectual Property Office (EIPO) did not hesitate to register this trademark. The petitioner stated its objections to the registration and the granting of certificate of registration and submitted its objections to $1^{\text {st }}$ respondent (Ethiopian Intellectual Property Office). The petitioner claimed that it had obtained registration certificate under the trademark "Ethio Cement" to use it for marketing its cement products.

According to the petitioner, allowing the $2^{\text {nd }}$ respondent to use this trademark will create confusion in a manner prejudicial to another trader. It claimed that using identical or similar distinguishing mark violates Article 141(2) of the

${ }^{30}$ Ethio-Cermaic P.L.C v. Ethiopian Intellectual Property office \& Ovorgiga Technology Limited, File No. 57179, Federal Supreme Court Cassation Division Decisions, Vol. 12, p.544- 548. 
Commercial Code, and the decision of the $1^{\text {st }}$ respondent contravenes Trade Practices Proclamation 329/2003 and Trademark Registration Proclamation $501 / 2006$. The Cassation Division reversed the decision of the $1^{\text {st }}$ respondent and decided that the $2^{\text {nd }}$ respondent cannot be allowed to use trademark for marketing its product.

In another case ${ }^{31}$ the Cassation Division rejected the filing of a legal action at the Federal Court of First Instance directly when one is dissatisfied by the decision of Ethiopian Intellectual Property Office. According to the Cassation Division, a person aggrieved by the decision of the Ethiopian Intellectual Property Office shall file an appeal at the Federal High Court. It appears that this is not consistent with the position it took under File No. 57179 (i.e., EthioCermaic P.L.C v. Ethiopian Intellectual Property office \& Ovorgiga Technology Limited). The Cassation Division has confirmed its position under File No $63454 .^{32}$

Article 17(1) of the Trademark Registration and Protection Proclamation No. $501 / 2006$ recognizes the right of an aggrieved party to appeal to a court having jurisdiction in connection with registration of trademark. However, the court to which an appeal can be lodged is not identified under the Proclamation. According to Article 49 of the Proclamation, "the Federal Courts shall have jurisdiction" but it does not specifically state whether it refers to the Federal Courts of First Instance or Federal High Court.

In spite of such challenges in terms of clarity and consistency, there are indeed commendable cassation decisions that give due attention to intellectual property rights. Cases in point are the decisions of the Federal Supreme Court Cassation Division with regard the copyright protection that should be accorded to translation works in File No. 44520 (20 October 2009) ${ }^{33}$ and the decision of the Cassation Division in File No. 68369 (January 13, 2012), ${ }^{34}$ which held that the form in which ideas are expressed are entitled to copyright protection even if the ideas are not original. This duly indicates that copyright protection refers to original expressions which might not necessarily emanate from new ideas or information.

${ }^{31}$ Ethiopian Intellectual Property Office v. Tibebe Ayele, File No. 59025, Federal Supreme Court Cassation Division Decisions, Vol. 12, pp. 549-553.

${ }^{32}$ Dat International Trading PLC owner Dr. Tenaye Abitew v. EIPO Y Civa Sante Pharmacy SA, File No 63454, Federal Supreme Court Cassation Division Decisions, Vol. 13, pp. 378-382.

${ }^{33}$ Artistic Printing Press v. Getahun Shiberu, File No. 44520, Federal Supreme Court Cassation Division Decisions Volume: 10, pp 339-341.

${ }^{34}$ Samuel Hailu \& Horizon Printing Press PLC -v. - Simret Ayalew, File No. 68369, Federal Supreme Court Cassation Division Decisions Volume 13, pp. 576-581 


\section{Conclusion: Challenges in Material and Non-financial Incentives}

The judicial system in Ethiopia has relatively clear structure and it includes federal and regional level courts. However there is increasingly growing concern about the level of competence in many courts which can be attributable to the unsatisfactory remuneration and other factors which need to be addressed so that judges with exemplary competence and integrity can be retained. The level of public confidence in relation with competence, impartiality and integrity needs utmost attention in the absence of which property rights cannot obtain the level of protection commensurate with the needs of private sector development

The judiciary can hardly attract and retain such judges under the current remuneration scale and prevailing non-financial incentives. Filipos Aynalem raises the question 'What is the salary that justice deserves to be paid?' and compares the remuneration scale of judges with other legal services in the context of the steadily rising cost of living such as housing rentals and transportation. He, among others, raises the salary scale in the Commercial Bank of Ethiopia for the Head of Legal Services, i.e. Over Birr 26,000 [an apparently deserved payment] vis-à-vis the extremely low salary range for judges which (subject to some variation in the future) was as follows in October 2013:

a) Birr 3,085 to Birr 5,243 for First Instance Court judges;

b) Birr 4,186 to 7,061 for Federal High Court Judges, and

c) Birr 5,051 to 7,890 for Supreme Court Justices. ${ }^{35}$

This raises the issue whether a country's treasury should generate revenue from court fees, or whether such fees can be ploughed back to the judiciary so that remuneration for judges can be significantly raised.

In the realm of non-financial incentives, there is the need to enhance rule of law, the independence of courts as enshrined in the Constitution and the tenure of judges. These factors coupled with the level of judicial scrutiny that should be put in place to harness discretionary powers of administrative entities determine the degree of law enforcement and the fairness, efficiency and predictability of judicial decisions that can enhance the complementarities between laws, administrative decisions and adjudication.

${ }^{35}$ Filipos Aynalem, "What is the salary that justice deserves to be paid?' (Yefitih demozwa sint new?), Addis Guday, Volume 7, No. 185, Tikimt 2, 2006 E.C.

(October 10, 2013), pp. 22-23. 